\title{
SELF-ASSESSMENT OF ATTITUDES OF THE LITHUANIAN AND EUROPEAN JUDO COACHES AND ATHLETES TOWARDS SPIRITUAL AND MORAL TRAITS OF THEIR PERSONALITY
}

\author{
Alma Kisieliené $\dot{e}^{1}$ Diana Arlauskaité ${ }^{2}$ \\ Lithuanian Academy of Physical Education ${ }^{1}$, Kaunas, Health and Sports Centre of Jurbarkas ${ }^{2}$, \\ Jurbarkas, Lithuania
} Alma Kisielienè. Master of Social Sciences (Education). Lecturer at the Department of Combat Sports, Lithuanian Academy of Physical
Education. Research interests - research in psychosocial health of people involved in combat sports.

\begin{abstract}
The aim of the research was to identify the self-assessment of the attitudes of the judo coaches and athletes possessing different levels of mastership towards their own spiritual traits and moral behaviour. The research was based on the assumption that different levels of sport mastership as well as age might influence the self-assessment of the personal attitudes of the judo sportsmen and coaches to their own spiritual traits and moral behaviour.

The research volume and organization. Following the aforementioned assumption, the four groups of the respondents were chosen: members of the Lithuanian National Youth Team of Judo $(n=20)$, their mean age was $17.2 \pm 1.25$ years; the youth elite of European judo, i.e. champions and prizewinners $(n=20)$, their mean age was $17.5 \pm 1.6$ years; Lithuanian judo coaches $(n=20)$, their mean age was $38.7 \pm 2.8$ years; and coaches of the champions and other prizewinners of contests $(n=20)$, their mean age was $40.5 \pm 3.6$ years.

The main method of research was an anonymous interview in writing. A questionnaire with closed questions aiming to analyze the self-assessment of the attitudes of the Lithuanian and European judo coaches and athletes towards their own spiritual traits and moral behaviour was worked out on the basis of the semiotic models offered by J. Dailidiene (1997). The questionnaire appendices provided a clear conceptual definition of each trait (the concepts were explained on the basis of L. Jovaiša (1993 a, b) "Dictionary of Pedagogic Terms" and "Principles of Education" (1993)). The respondents were asked to mark their personal consideration of all the traits that were characteristic of them. By following Dalidiene's suggestion, they were grouped into two blocks: the ones related with morality and the ones related with spirituality.

Mathematical statistics. The data were analyzed by employing the statistic data analysis software SPSS 13.0 applying the method of descriptive statistics. The reliability of the difference between the groups was estimated on the basis of the chi square criterion. When its value was $p<0.05$, the differences were regarded as statistically significant.

The majority of the Lithuanian and European judo coaches and athletes included diligence (85-100\%) and persistency (60-90\%) into their Self-image. Lithuanian judo coaches $(p<0.05)$ distinguished courageousness as their common trait, whereas the European judo coaches $(p<0.05)$ distinguished dutifulness and fellow-feeling; a significant part of the European judo elite athletes $(p<0.05)$ emphasized friendliness and attentiveness.
\end{abstract}

Keywords: self-assessment of judo coaches and judo athletes, spiritual features, moral features.

\section{INTRODUCTION}

$\mathrm{S}$ pirituality reveals a human being as a person independently interacting with other human beings, human communities, oneself, nature and the transcendental world and shows his/her approach to universal spiritual values that raise above particular everyday situations. (Martišauskienė, 2004 a). Some Lithuanian philosophers are apt to connect spirituality with an outspread of religious values (Šalkauskis, 1992), an expression of humanism (Vydūnas, 1990), or morality (Maceina,
1936; Navickas, 1988) and with person's ethical position (Kuzmickas, 1977). The psychological scientific sources concentrate on continuous maturation or the process of the formation of a human personality embracing various levels of life that grow into important maturity stages (Erikson, 1996) related with the spread of belief (Fawler, 1984) and moral intellectual development (Kohlberg, 1984). From the point of view of a number of education specialists, spirituality is often 
understood as an expression of human freedom (Montesori, 1964) or public spirit (Groome, 2000), a conscious evaluation of experience (Groome, 2000), an expression of religious values (DarcyBerube, 1995), the sense of faith (Killen, Beer, 1999), etc. Every aspect of human experience is integrated into the concept of spirituality: sensual, religious, psychological, historical, political, social, etc. Therefore, a contemporary approach to spirituality requires an interdisciplinary perspective that encompasses the attitudes and means offered by various fields of science (Verbylaite, 2006).

The majority of the scholars stress the importance of the development of an adequate selfassessment of private actions in the education process. Its role in the formation of purposeful self-determination (Pikūnas, 1990), moral orientation and position (Navickas, 1988), moral ideals (Martišauskienè, $2004 \mathrm{~b}$ ), the development of the faculty of conscience (Paškus, 1998), the impact on the education process (Šerkšnas, 1937), selfeducation (Vydūnas, 1990) has been firmly determined. With an increasing amount of the scientific inquiries in the field of self-assessment and the deepening conception of individual morality, the possibilities are open for the self-assessment of actions and for the moral formation of the personality (Martišauskiene, 2004 b). By recognizing the multi-level operation of the impact of morality, its significance and universal character, the representatives of philosophy and hodogetics are inclined to associate the content of spirituality with moral values. Most scholars agree that morality is the main, yet not the only condition determining the subject of spirituality.

It goes without saying that sport plays an important role in culture by forming a harmonious personality. For people, sports activity reveals up many moral principles. However, the contemporary society abounds in examples where the methodical experience of the development of the physical powers of a person has been used by the representatives of the criminal world who completely eliminate the spiritual component during their actions (Tamošauskas, 2000). Therefore, the content of physical education should be oriented to the internal rather than external actions of an individual, his / her psychological and moral faculties. It should help to form the person's global outlook, the system of moral values and the attitudes toward sports. The mentioned aspects constitute the kernel of the sport value internalization. With the help of an established moral orientation, an individual is able to select what is most important for him / her (Tamošauskas, 2000). For instance, Stoliarov and Samusenkova (1996, cit. from Šukys, Kardelis, 2001) claim that sports may form an independent branch of subculture as well as develop such personal values that differ from the publicly accepted ones.

Although the subject of athletes' self-assessment of the attitudes to their own spirituality and moral behaviour has not been widely analyzed, it still remains a relevant issue requiring considerable investigation.

\section{METHODS}

The aim of the research was to identify the self-assessment of the attitudes of the judo coaches and athletes possessing different levels of mastership to their own spiritual traits and moral behaviour. The research was based on the assumption that different levels of sport mastership as well as age might influence the self-assessment of the personal attitudes of the judo athletes and coaches to their own spiritual traits and moral behaviour.

The research volume and organization. Following the aforementioned assumption, the four groups of the respondents were chosen: the members of the Lithuanian National Youth Team of Judo $(n=20)$, their mean age was $17.2 \pm 1.25$ years; the youth elite of European judo, i.e. champions and prizewinners $(n=20)$, their mean age was $17.5 \pm 1.6$ years; Lithuanian judo coaches $(n=20)$, their mean age $-38.7 \pm 2.8$ years; and the coaches of the champions and other prizewinners of contests $(n=20)$, their mean age $-40.5 \pm 3.6$ years. In total, 80 respondents were questioned during the research.

The main method of research was an anonymous interview in writing. A questionnaire with closed questions aiming to analyze the selfassessment of the attitudes of the Lithuanian and European judo coaches and athletes to their own spiritual traits and moral behaviour was worked out on the basis of the semiotic models offered by J. Dailidiene (1997). The semiotic model is the hiearchy of the dependency and relations between signs and sign systems interconnected by similar notional parameters that are relatively shown by certain indicators, their elements - i.e. semantic units - and the words which give an additional explanation. For instance, the semiotic model of spirituality involves the following indicators: love, compliance, mercifulness, etc. The processal ele- 
ments of the indicators are the synonymous forms of the words. For instance, the processal elements of the indicator mercifulness are regrettable, to feel sorry for, etc. Various semantic units explain the processal elements. For instance, the processal element is sorry may be explained by the words caresses, comforts, etc. As a rule, the semantic units are unified by the more general processal elements that lead to a right conception of the behavioural rules and norms. Such elements, in their turn, are unified by the indicators operating as the nomination and conception of moral and spiritual values that lead to a higher level of the development of consciousness (i.e. field of motivations). The latter determines the following modus: Individual $\rightarrow$ microenvironment $\rightarrow$ existential and transcendental Entity (Dailidienè, 1997).

The questionnaire appendices provided a clear conceptual definition of each feature (the concepts were explained on the basis of L. Jovaiša (1993 a, b) "Dictionary of Pedagogic Terms" and "Principles of Education"). The inquest was done by D. Arlauskaite. The respondents were asked to mark their personal consideration of all the traits that were characteristic of them. By following Dalidiene's suggestion, they were grouped into two blocks: the ones related with morality and the ones related with spirituality. The block related with the aspect of morality involved dutifulness, friendliness, civility, persistency, diligence, courageousness, modesty, self-restrain, responsibility and conformity. The block related with the aspect of spirituality embraced fellow-feeling, altruism, generosity, patience, mercifulness, tenderness, compliance, fairness, attentiveness, forgiveness, tolerance, piety and kindness. The Lithuanian athletes and coaches were interviewed in Lithuania during their preparation for the European Youth Championship. In order to compare the moral and spiritual traits of the Lithuanian and European coaches and athletes, an English version of the anonymous questionnaire was worked out and submitted to the athletes belonging to the European youth elite (i.e. champions and prizewinners) and their coaches during the Judo European Championship that took place in Rome.

Mathematical statistics. The data was analyzed by employing the statistic data analysis software SPSS 13.0 applying the method of descriptive statistics. The reliability of the difference between the groups was estimated on the basis of the chi square criterion. With the value of $p<0.05$, the differences were regarded as statistically significant.

\section{RESULTS}

The morality-related interviews showed (see Table 1) that an overall majority of the interviewed people specified diligence as their dominant trait: $20(100 \%)$ European Judo Championship medalists, 19 (95\%) Lithuanian judo coaches, 18 (90\%) coaches of the European prize winners and 17 (85\%) members of the Lithuanian National Team.

Most of the European prize winners 18 (90\%) and European judo coaches 17 (85\%), as well as more than a half of the Lithuanian judo coaches $13(65 \%)$ and Lithuanian judo sportsmen 12 (60\%) characterized themselves as persistent persons.

Dutifulness was characteristic of the European judo coaches 17 (85\%), less characteristic of the Lithuanian coaches $12(60 \%)$ and the European judo elite athletes $12(60 \%)$ and still less of the Lithuanian judo athletes $8(40 \%), \chi^{2}=8.58$; $\mathrm{df}=3 ; \mathrm{p}<0.05$.

It is interesting to note that most of the Lithuanian judo coaches $18(90 \%)$ characterized themselves as courageous individuals, yet only $9(46 \%)$ Lithuanian judo coaches and $5(25 \%)$ members of the Lithuanian National Team confessed of being courageous persons. However, the European prize winners did not distinguish such a trait of their personality $(0 \%), \chi^{2}=34.81 ; \mathrm{df}=3$; $\mathrm{p}<0.05$. The majority of the European prize winners $13(65 \%)$ reckonned themselves among highly responsible persons. Half of the European coaches $10(50 \%), 7(35 \%)$ Lithuanian coaches and as few as $4(20 \%)$ members of the Lithuanian National Team expressed the same opinion $\chi^{2}=9.21 ; \mathrm{df}=3 ; \mathrm{p}<0.05$. All the respondents had an identical consideration of civility: in fact, none of them mentioned this aspect at all.

15 (75\%) European championship medalists, $9(45 \%)$ Lithuanian athletes and considerably fewer European 5 (25\%) and Lithuanian 4 (20\%) coaches described themselves as friendly people $\left(\chi^{2}=15.42 ; \mathrm{df}=3 ; \mathrm{p}<0.05\right)$.

All the discussed four groups of the respondents demonstrated low consideration of modesty, self-restraint and adjustment in communication with other people.

The analysis of the respondents' self-assessment with respect to spirituality (close to Christian morality) revealed more differences among the tested groups (see Table 2) than in the case of the morality-based self-assessment.

Fellow-feeling is most characteristic of the European judo coaches 17 (85\%) and consider- 


\begin{tabular}{|c|c|c|c|c|c|c|c|}
\hline \multirow[b]{2}{*}{ Feature } & \multicolumn{4}{|c|}{ Respondent groups, \% } & \multicolumn{3}{|c|}{ Pearson's Chi-Square } \\
\hline & $\begin{array}{l}\text { Lithuanian } \\
\text { judo coaches }\end{array}$ & $\begin{array}{l}\text { European } \\
\text { judo coaches }\end{array}$ & $\begin{array}{l}\text { Lith. Jun. } \\
\text { Nat. Judo } \\
\text { Team } \\
\end{array}$ & $\begin{array}{l}\text { Eur. Judo } \\
\text { Champ. } \\
\text { medallists }\end{array}$ & Value & df & $\begin{array}{l}\text { Asymp. Sig. } \\
\text { (2-sided) }\end{array}$ \\
\hline Dutifulness & 60.0 & 85.0 & 40.0 & 60.0 & 8.585 & 3 & 0.035 \\
\hline Friendliness & 20.0 & 25.0 & 45.0 & 75.0 & 15.422 & 3 & 0.001 \\
\hline Civility & 0 & 0 & 0 & 0 & - & - & - \\
\hline Persistency & 65.0 & 85.0 & 60.0 & 90.0 & 6.933 & 3 & 0.074 \\
\hline Diligence & 95.0 & 90.0 & 85.0 & 100 & 3.604 & 3 & 0.308 \\
\hline Courageousness & 90.0 & 45.0 & 30.0 & 0 & 34.816 & 3 & 0.00 \\
\hline Modesty & 15.0 & 20.0 & 25.0 & 10.0 & 1.732 & 3 & 0.630 \\
\hline Self-restraint & 25.0 & 10.0 & 5.0 & 15.0 & 3.689 & 3 & 0.297 \\
\hline Responsibility & 35.0 & 50.0 & 20.0 & 65.0 & 9.207 & 3 & 0.027 \\
\hline Conformity & 25.0 & 10.0 & 5.0 & 0 & 7.778 & 3 & 0.051 \\
\hline
\end{tabular}

\begin{tabular}{|c|c|c|c|c|c|c|c|c|}
\hline \multirow[b]{2}{*}{ Feature } & \multicolumn{4}{|c|}{ Respondent groups, \% } & \multicolumn{3}{|c|}{ Pearson's Chi-Square } & \multirow{15}{*}{$\begin{array}{l}\text { Table 2. Spirituali- } \\
\text { ty-related self-as- } \\
\text { sessment of judo } \\
\text { coaches and athle- } \\
\text { tes }\end{array}$} \\
\hline & $\begin{array}{l}\text { Lith. judo } \\
\text { coaches }\end{array}$ & $\begin{array}{l}\text { Eur. judo } \\
\text { coaches }\end{array}$ & $\begin{array}{l}\text { Lith. Jun. } \\
\text { Nat. Judo } \\
\text { Team }\end{array}$ & $\begin{array}{l}\text { Eur. Judo } \\
\text { Champ. } \\
\text { medalists }\end{array}$ & Value & df & $\begin{array}{l}\text { Asymp. Sig. } \\
\text { (2-sided) }\end{array}$ & \\
\hline Fellow-feeling & 45.0 & 85.0 & 25.0 & 0 & 32.600 & 3 & 0.000 & \\
\hline Altruism & 0 & 0 & 0 & 0 & - & - & - & \\
\hline Generosity & 25.0 & 20.0 & 15.0 & 25.0 & 0.822 & 3 & 0.844 & \\
\hline Patience & 50.0 & 65.0 & 0 & 0 & 33.379 & 3 & 0.000 & \\
\hline Mercifulness & 35.0 & 20.0 & 0 & 20.0 & 8.123 & 3 & 0.044 & \\
\hline Tenderness & 60.0 & 45.0 & 25.0 & 50.0 & 5.253 & 3 & 0.154 & \\
\hline Compliance & 0 & 0 & 0 & 0 & - & - & - & \\
\hline Fairness & 25.0 & 35.0 & 15.0 & 35.0 & 6.77 & 3 & 0.168 & \\
\hline Attentiveness & 0 & 0 & 10.0 & 45.0 & 23.083 & 3 & 0.000 & \\
\hline Forgiveness & 0 & 25.0 & 0 & 60.0 & 28.908 & 3 & 0.000 & \\
\hline Tolerance & 70.0 & 85.0 & 25.0 & 0 & 37.576 & 3 & 0.000 & \\
\hline Piety & 60.0 & 75.0 & 0 & 75.0 & 30.677 & 3 & 0.000 & \\
\hline Kindness & 10.0 & 30.0 & 40.0 & 35.0 & 5.065 & 3 & 0.167 & \\
\hline
\end{tabular}

ably less characteristic of the Lithuanian coaches 9 (45\%). As few as 5 (25\%) Lithuanian sportsmen indicated such an aspect. Fellow-feeling appeared to be alien to the European medalists $\left(\chi^{2}=32.6\right.$; $\mathrm{df}=3 ; \mathrm{p}<0.05)$ as well. With reference to the questionnaire data, patience was found most characteristic of the European judo coaches 13 (35\%) and half of the Lithuanian coaches $10(50 \%)$. However, it appeared to be of no consideration on the part of the Lithuanian and European athletes $(0 \%)\left(\chi^{2}=33.37 ; \mathrm{df}=3 ; \mathrm{p}<0.05\right)$.

Mercifulness might be attributed to about one third of all the Lithuanian judo coaches 7 (35\%), a quarter of the European judo coaches $4(20 \%)$ and a quarter of the European judo youth elite $4(20 \%)$. However, Lithuanian athletes did not distinguish such a trait at all $(0 \%)\left(\chi^{2}=8.12\right.$; $\mathrm{df}=3 ; \mathrm{p}<0.05)$.

Piety appeared to be characteristic of the majority of the European respondents, 15 (75\%) European coaches and $15(75 \%)$ athletes as well as $12(60 \%)$ Lithuanian coaches. None of the members of the Lithuanian Junior National Judo

Table 1. Moralityrelated self-assessment of judo coaches and athletes (n)

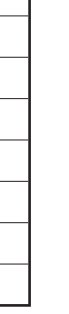


dents thought that these traits were not characteristic of them.

No reliable differences were found while analyzing the self-assessment of the respondents with respect to fairness, generosity, tenderness and kindness. Approximately a third part of the European trainers and athletes described themselves as fair persons (a quarter of the Lithuanian coaches and $15 \%$ of the Lithuanian judo athletes). Tenderness appeared to be characteristic of the majority of the Lithuanian judo coaches $12(60 \%)$, a half of the European athletes $10(50 \%), 9(45 \%)$ Lithuanian athletes and the same number of the European judo coaches. Kindness and generosity were characteristic of a third part and a quarter of all the respondents respectively.

\section{DISCUSSION}

The research aimed at the indication of the ways of how the judo coaches and athletes demonstrating different levels of mastership evaluated themselves regarding spiritual traits and moral behaviour. Overall of 80 respondents were interviewed: 20 European judo athletes belonging to youth elite and 20 of their coaches; 20 members of the Lithuanian Judo Youth National Team and 20 of their coaches.

Aiming to reduce the risk of inaccuracy, which could be determined by the semantic differences between the Lithuanian and the English languages when the concepts with an allied meaning might be treated ambiguously by the different groups of the respondents (i.e. Lithuanians and non-Lithuanians), a modified variant of the semiotic methodology offered by J. J. Dailidienè (1997) was applied.

According to the research data, diligence was the most typical trait distinguished by $85-100 \%$ of all the respondents and especially by the judo elite athletes $(100 \%)$. The authors of the paper believe that this feature, as well as the commonly distinguished persistency $(60-90 \%)$, reflected an everyday situation of the Great Sport full of enormous physical and psychological strains. It should be pointed out that it showed the tested respondents belonging to the specific part of a contemporary society. This might be the reason why the analyzed data differed from the conclusions drawn by E. Martišauskienè (2004 a) who considered that elder teenagers rather rarely embodied altruism defined by her as self-sacrifice and devotion to work (see Rokeach, 1985). All the respondents who participated in the given research ignored altruism $(0 \%)$ which was defined by the authors of the paper as an unselfish concern about the wellfare of other people. Yet in this respect, the results were close to the generalizations concerning the orientation of the Lithuanian teenagers obtained by E. Martišauskiene (2004 b).

While comparing the Self-image of the Lithuanian and the European elite athletes, many differences in the choice of the spiritual and moral features were indicated. The athletes belonging to the European judo elite were eager to ascribe diligence, persistence, responsibility $\left(\chi^{2}=9.2 ; \mathrm{df}=3\right.$; $\mathrm{p}<0.05)$, dutifulness $\left(\chi^{2}=8.58 ; \mathrm{df}=3 ; \mathrm{p}<0.05\right)$, friendliness $\left(\chi^{2}=15.42 ; \mathrm{df}=3 ; \mathrm{p}<0.05\right)$, attentiveness $\left(\chi^{2}=23.08 ; \mathrm{df}=3 ; \mathrm{p}<0.05\right)$, mercifulness $\left(\chi^{2}=8.12 ; \mathrm{df}=3 ; \mathrm{p}<0.05\right)$ and forgiveness $\left(\chi^{2}=28.9 ; \mathrm{df}=3 ; \mathrm{p}<0.05\right)$ to themselves more frequently than the Lithuanian athletes. It is likely that it might be influenced not solely by the cultural differences, but also by a higher degree of self-assessment among elite athletes. The obtained data showed no objection to C. Robaza's (2006) assumption that the increase of the sporting experience and mastership among the judo athletes was marked by self-confidence and an ability to control personal emotions. It should be recognized that in combat sports it is one of the most essential factors together with the technical-tactical qualification that influence good results. C. Robaza (2006) states that the development of the psychological skills of the athletes who posses a high level of mastership do affect the sport results positively.

A. Antonovsky (1987), the originator of the $s a$ lutogenic theory, analyzed the physically and psychologically healthy individuals who were enduring long-lasting and extremely stressful situations for a few decades. He extended the hypothesis of the existence of the so-called construct of internal harmony reflecting an individual's ability to react to various stressful situations and directly influencing his / her physical and psychological states. According to Antonovsky, the construct of internal harmony is maintained by various factors: perception of life meaningfulness, optimism, religion (belief), etc. The more sources the individual gets to dispose, the more he / she is resistant. Thus, the carried out research demonstrated that the majority of the European (75\%) elite athletes, Lithuanian $(60 \%)$ and European coaches (75\%) were pious persons, whereas none of the Lithuanian athletes distinguished this feature $\left(\chi^{2}=30.67 ; \mathrm{df}=3\right.$; $p<0.05)$. According to Antonovsky's theoretical frame, it might be interpreted that the respondents 
who described themselves as pious people (i.e. believing in God) successfully disposed of this feature as a means for stress-reduction and an increase of confidence in all stressful situations, including sport contests.

The assessment of courageousness defined as absence of fear offered the contradictory data $\left(\chi^{2}=34.81 ; \mathrm{d}=3 ; \mathrm{p}<0.05\right)$. The majority of the Lithuanian coaches (90\%) distinguished this trait; yet less than a half of the European coaches did it. Supposedly, the courageousness of the Lithuanian judo coaches might have been influenced by the critical economical situation in sports, since beside their direct work with athletes, the coaches were also forced to look for the opportunities for the athletes of high level of mastership to participate in the Lithuanian and foreign training camps and matches. Surprisingly enough, no less than a third part of the Lithuanian sports people considered themselves fearless; yet none of the European athletes distinguished this trait. It should be stressed that the majority of the respondents whose answers were negative could not be considered timid; they might have been apt to evaluate the risk consciously in any situation including sport contests.

In the estimation of friendliness, differences in opinion were observed. The Lithuanian athletes and the European judo elite athletes distinguished this feature twice $(45 \%)$ and three times $(75 \%)$ more frequently than their coaches $\left(\chi^{2}=15.42 ; d=3\right.$; $\mathrm{p}<0.05$ ). It could be explained by the fact that in general athletes posses a narrower scope of interests and it often determines the choice of the referential group consisting of other teenagers just doing sports (Винник, 1991, cit. by Šukys and Kardelis, 2001). He also claims that the most important and essential value among the teenagers (especially boxers) is good and faithful friends. However, the scholars emphasize that this value is more popular among the teenagers who are doing sports. Consequently, it is influenced not solely by the specificity of sports, but rather appears to be one of the most essential needs experienced by the teenagers - a need to communicate and be accepted by other teenagers.

The coaches tend to distinguish the spiritual aspects more frequently than their athletes do. The Lithuanian and European coaches claim to posses such traits as fellow-feeling, patience and tolerance $(\mathrm{p}<0.05)$. Such results might be influenced by the age of the interviewed athletes $(16-20$ year-olds). The authors of the cognitive orientation (Kohlberg, 1984) who focus on the aspect of cognitive and ethic development of the personality emphasize that human reasoning changes due to ageing. Therefore, the conception of values and their assimilation depend on the level of personal maturity. According to A. Antonovsky (1987), the construct of internal harmony that reflects the personal ability to react properly to stressful situations undergoes its complete formation around thirty years of age.

The Lithuanian and European coaches and athletes distinguished the moral features at a greater extent in comparison with the spiritual ones. Such tendency is particularly distinct when analyzing the opinions expressed by the athletes. The data of the given research coincides with the data provided by E. Martišauskienè (2004 a) who analyzed the spiritual problems of the Lithuanian teenagers. She stated that teenagers prefered an acknowledgement of the moral values rather than the personal relation with the transcendence (i.e. God).

The Lithuanian and European coaches and both groups of athletes thought that morality to them was more important than spirituality. Such tendency becomes even more evident in analyzing the attitudes of the athletes. The obtained results coincide with the data obtained by E. Martišauskiene (2004 b) in her investigation of the moral problems associated with the senior teenagers. The scholar stresses that the senior teenagers are prone to accentuate the moral values rather than reveal their personal relation with the transcendence (i.e. God).

Research literature (Collins, Hale, 1995, cit. by Šukys, Kardelis, 2001) tends to discuss the negative impact of the martial sports on the development of the personality. It is supposed that they evoke strong aggressiveness towards others. Society is also apt to associate such sports with the cult of power.

The results of the research showed that the athletes demonstrating a higher level of mastership tend to include the spiritual and moral elements into their Self-image more often than those demonstrating the medium level of mastership. Consequently, it confirms the hypothesis that a different level of the sport experience as well as differences in age influence the athletes and coaches' self-assessment of the attitudes to their own spiritual and moral traits. However, it should be noted that these are not the only factors that influenced the results of the research. The respondents' self-assessment in relation to cultural differences whose estimation was rather complicated should also be taken into consideration, as athletes and coaches of the European judo elite are, in fact, the representatives 
of different types of culture and belong to different nations. For instance, the European respondents (i.e. judo coaches and athletes) included into such traits as their Self-image, dutifulness, responsibility and forgiveness at a greater extent than the Lithuanian respondents (i.e. judo coaches and athletes) $(\mathrm{p}<0.05)$. Nevertheless, the comparative analysis of the athletes and coaches' interview showed more notable differences.

The formation of the pro-social models of behaviour in sports determines the importance of the role of the coach whose personal sports philosophy is found to be based on the perception of personal ethics that depends on individual convictions, attitudes and values. All the above mentioned factors have a direct impact on the coaches' moral solutions which are important in decision making in the field of sports. No doubt, the coach should pass his/her sports philosophy on to the athletes (see Lumpkin, Cuneen, 2001). Nevertheless, the data obtained by S. G. McCalister, E. M. Blinde and W. M. Weiss (2000) demonstrate that it is not a frequent practice among the coaches to pass their sports philosophy on to the athletes and their solutions are not often based on their personal convictions. Moreover, the coaches seem not to be willing to disclose their attitudes to the fullest scale (see Bergman-Drewe, 2000).

The results of the research show that the judo trainers tend to include moral features, especially the spiritual ones, into their Self-image. Yet, being the most important figures in the development of the athletes' personalities, they should not only possess their own sports philosophy and follow the universally accepted moral attitudes, but also impart them to the athletes whom they train.

\section{CONCLUSIONS}

1. The majority of the Lithuanian and European judo coaches and athletes included diligence $(85-100 \%)$ and persistency $(60-90 \%)$ into their Self-image.

2. The majority of the Lithuanian judo coaches $(p<0.05)$ distinguished courageousness as their common trait, whereas the European judo coaches $(\mathrm{p}<0.05)$ distinguished dutifulness and fellow-feeling; a significant part of the European judo elite athletes $(p<0.05)$ accentuated friendliness and attentiveness.

3. The European respondents (both coaches and athletes) included dutifulness, responsibility and forgiveness into their Self-image more often than the Lithuanian respondents (both coaches and athletes $)(\mathrm{p}<0.05)$.

4. The Lithuanian and European coaches distinguished tolerance, fellow-feeling and patience more often than the athletes. Contrarily, the athletes distinguished fellow-feeling more often than their coaches $(\mathrm{p}<0.05)$.

5. The European judo elite athletes distinguished responsibility, dutifulness, friendliness, attentiveness, piety, mercifulness and forgiveness more often than the Lithuanian athletes $(\mathrm{p}<0.05)$.

6. The Lithuanian and European judo coaches and especially their athletes preferred to include the moral traits rather than the spiritual ones into their Self-image.

\section{REFERENCES}

Antonovsky, A. (1987). Unraveling the Mystery of Health. How People Manage Stress and Stay Well. San Francisco: Jossey-Bass.

Bergman-Drewe, S. (2000). Coaches, ethics and autonomy. Sport, Education and Society, 5 (2), 147-162.

Dailidienè, J. J. (997). Vaiko kalba - vaiko dvasia. Kaunas: Šviesa.

Darcy-Berube, F. (1995). Religious Education at a Crosssroads: Moving On in the Freedom of the Spirit. New York: Paulist press.

Dykstra, C. (1999). Growing in the Life of Faith. Lousville, Kentuky: Geneva Press.

Erikson, E. H. (1968). Identity: Youth and Crisis. New York: Norton.

Fowler, J. W. (1984). Becoming Adult, Becoming Christian. San Francisco: Harper and Row.

Groome, T. (2000). The Way of Sharied praxis. Stokholm: Institute of Pedagogy in Religion.

Jovaiša, L. (1993 a). Edukologijos pradmenys. Vilnius.
Jovaiša, L. (1993 b). Pedagogikos terminai. Kaunas.

Killen, P. and De Beer, J. (1999). The Art of Theological Reflection. New York: Crossroad.

Kohlberg, L. (1984). Essays on Moral Development: The Psychology of Moral Development. San Francisco: Harper and Row.

Kuzmickas, B. (1977). Katalikiškasis transcendentinis humanizmas. Vilnius.

Lumpkin, A., Cuneen, J. (2001). Developing a personal philosophy of sport. Journal of Sport Education, Recreation and Dance, 72 (8), 40-43.

Maceina, A. (1936). Lavinimas ir auklejjimas. Lietuvos mokykla, 1, 6-11.

Martišauskienė, E. (2004 a). Dvasinių vertybių įsikūnijimas paaugliu elgesyje. Acta Paedagogica Vilnensia, 13, 53-61.

Martišauskienè, E. (2004 b). Pedagoginių veiksnių itaka vyresniujuc paauglių dvasiniam tapsmui. Acta Paedagogica Vilnensia, 12, 136-148. 
McCallister, S. G., Blinde, E. M., Weiss, W. M. (2000). Teaching values and implementing philosophies: Dilemmas of the youth sport coach. The Physical Educator, 57 (1), 35-45.

Montessori, M. (1964). The Montessory Method. New York: Schochen books.

Navickas, J. L. (1988). Dorove ir vertybès. Vilnius.

Paškus, A. (1998). Tikejjimo ir netikejjimo sqlytis šiandien. Kaunas: Lietuvos Katechetikos centro leidykla.

Pikūnas, J. (1990). Nuo asmens iki asmenybès. Chicago.

Robazza, C., Bertollo, M., Bortoli, L. (2006). Frequency and direction of competitive anger in contact sports. The Journal of Sports Medicine and Physical Fitness. Vol. 46, $3,501-508$.
Rokeach, M. (1985). The Nature of Human Values. New York.

Šalkauskis, S. (1992). Rinktiniai raštai. Pedagoginès studijos. Kn. 1. Vilnius: Leidybos centras.

Šerkšnas, A. (1937). Klasès bendruomenè. Lietuvos mokykla, 1, 5-8.

Šukys, S., Kardelis, K. (2001). Paaugliu aktyvios fizinès veiklos ir vertybinių orientacijų sąsaja. Sporto mokslas, 4 (26), 58-63.

Tamošauskas, P. (2000). Humanistiškai orientuotas studentu fizinis ugdymas: monografija. Vilnius: VGTU „Technika“.

Verbylaite, D. (2006). Dvasingumas ir jo ugdymo galimybès universitete: monografija. Siauliai: Śiaulių universiteto leidykla.

Vydūnas. (1990). Raštai. T. 1. Vilnius.

\title{
LIETUVOS IR EUROPOS DZIUDO TRENERIŲ, SPORTININKŲ SAVO ASMENYBĖS DVASINGUMO IR DOROVINIŲ SAVYBIŲ VERTINIMAS
}

\author{
Alma Kisieliené $\dot{e}^{1}$, Diana Arlauskaité ${ }^{2}$ \\ Lietuvos kūno kultūros akademija, Kaunas ${ }^{1}$, Jurbarko sveikatingumo ir sporto centras, Jurbarkas ${ }^{2}$, \\ Lietuva
}

\section{SANTRAUKA}

Tyrimo tikslas - nustatyti skirtingo meistriškumo dziudo sportininkų ir treneriu savo asmenybès dvasingumo ir dorovinių savybių vertinimą.

Pasirinktos keturios tiriamuju grupès: Lietuvos dziudo jaunimo rinktinès nariai $(n=20)$, amžiaus vidurkis - 17,2 $\pm 1,25$ m.; Europos dziudo jaunimo elitas, t. y. čempionato nugalètojai ir prizininkai $(\mathrm{n}=20)$, amžiaus vidurkis $-17,5 \pm 1,6 \mathrm{~m}$.; Lietuvos dziudo treneriai $(\mathrm{n}=20)$, amžiaus vidurkis $-38,7 \pm 2,8 \mathrm{~m}$.; Europos jaunimo čempionato nugalètojų ir prizininkų treneriai $(\mathrm{n}=20)$, amžiaus vidurkis $-40,5 \pm 3,6 \mathrm{~m}$.

Pagrindinis tyrimo metodas - anoniminè apklausa raštu. Remiantis J. Dailidienès (1997) pateiktais dvasingumo ir dorovingumo semiotiniais modeliais, sudarytas uždaro tipo klausimynas. Klausimyno priede buvo apibrěžta kiekvieno bruožo samprata (sąvokas aiškinant pagal L. Jovaišos (1993 a, b) „Edukologijos pradmenis“ ir „Pedagogikos terminų žodyną“). Pagal J. Dailidienę (1997) jos buvo suskirstytos į du blokus: dorovingumo ir dvasingumo. Lietuvos sportininkai ir treneriai apklausti Lietuvoje pasirengimo Europos jaunimo čempionatui metu. Norint palyginti Lietuvos ir Europos treneriu, sportininkų dvasingumo ir dorovingumo bruožus, anglų kalba parengti klausimynai pateikti Europos jaunimo elito (t. y. čempionato nugalètojams ir prizininkams) sportininkams ir jų treneriams Europos čempionato metu Romoje.

Duomenys buvo analizuojami naudojantis statistine duomenu analizès programine įranga SPSS 13.0 for Windows. Naudota aprašomoji statistika, skirtumo tarp grupių patikimumas įvertintas pagal chi kvadrato kriterijų. Skirtumas laikytas statistiškai reikšmingu, kai $\mathrm{p}<0,05$.

Didžioji dauguma Lietuvos ir Europos dziudo trenerių, sportininkų i savo savivaizdị itraukẻ darbštumą (85-100̣) ir atkaklumą (60-90̣). Drąsumą, kaip sau būdingą, pripažino išskirtinai daug Lietuvos dziudo treneriu $(\mathrm{p}<0,05)$, pareigingumu ir atjauta išsiskyre Europos dziudo treneriai $(\mathrm{p}<0,05)$, o draugiškumu ir atidumu didesnè dalis Europos dziudo elito sportininku $(\mathrm{p}<0,05)$. Europos respondentai (dziudo treneriai ir sportininkai) i savo Aš vaizdą dažniau įtraukẻ pareigingumą, atsakingumą ir atlaidumą nei Lietuvos respondentai (dziudo treneriai ir sportininkai) $(\mathrm{p}<0,05)$.

Raktažodžiai: dziudo treneriu ir dziudo sportininkų savęs vertinimas, dvasingumo bruožai, dorovingumo bruožai.

Gauta 2007 m. birželio 5 d.

Received on June 5, 2007

Priimta 207 m. rugsèjo 19 d

Accepted on September 19, 2007
Alma Kisielienè

Lithuanian Academy of Physical Education

(Lietuvos kūno kultūros akademija)

Sporto str. 6, LT-44221 Kaunas

Lithuania (Lietuva)

Tel +370 37302664

E-mail almakisieliene@takas.lt 